\title{
AKUNTAN DALAM INDUSTRI 4.0: STUDI KASUS KANTOR JASA AKUNTAN (KJA) DI WILAYAH KEPULAUAN RIAU
}

\author{
Alfonsa Dian Sumarna \\ Program Studi Akuntansi, Politeknik Negeri Batam \\ alfonsadian@polibatam.ac.id \\ DiPublikasi: 01/01/2020 \\ http: / /dx.doi.org/10.22225/kr.11.2.1255.100-109
}

\begin{abstract}
Using robotics and data analytics (big data) can over take clerical job (data entry, bookkeeping, compliance work). Accounting profession underestimate to technologies. Competence such as data analysis, information technology development, and leadership skills must be adapted to face 4.0. Our research found that Kantor Jasa Akuntan in Kepulauan Riau Province using $80 \%$ accounting professional labor (accounting bachelor). This research confirmed about IoT (Internet of Things) that $60 \%$ of KJA use 70-100\% of total hours of work using computer (software) and internet compare with manual working. KJA need accounting professional who able to work with software such as accounting software, statistic, Ms Office, Zahir, and SAP. This research also found the main softskill needed is critical thingking ability. Acording to the survey, software are not affecting accounting employment yet.
\end{abstract}

Keywords: Industry 4.0; Accounting Professional; Software; Internet of Things

\begin{abstract}
Abstrak
Penggunaan robotics dan data analytics (big data) dapat mengambil alih pekerjaan dasar yang dilakukan oleh akuntan (mencatat transaksi, mengolah transaksi, dan memilah transaksi). Profesi akuntan merasa dirugikan terkait dampak teknologi terhadap pekerjaan akuntan. Kompetensi yang penting bagi profesi akuntan dalam menghadapi 4.0 misalnya data analysis, information technology development, dan leadership skills harus dapat dikembangkan. Penelitian ini menunjukkan bahwa Kantor Jasa Akuntan di Wilayah Provinsi Kepulauan Riau masih tetap mempertahankan menggunakan tenaga profesional akuntan sebesar $80 \%$ merupakan Sarjana Akuntansi. Selain itu penelitian ini juga mengkonfirmasi penggunaan IoT (Internet of Things) yaitu sebesar $60 \%$ KJA menggunakan $70-100 \%$ total waktu menyelesaikan pekerjaan menggunakan komputer (software) dan internet dibandingkan dengan pengerjaan manual. KJA membutuhkan akuntan profesional yang menguasai software akuntansi, statistika, MsOffice, Zahir dan SAP. Selain menguasai software dalam menghadapi 4.0, penelitian ini menunjukkan bahwa softskill utama yang diperlukan adalah memiliki kemampuan berpikir kritis dan analitis.
\end{abstract}

Kata Kunci: Industri 4.0; Akuntan Profesional; software; Internet of Things

\section{PENDAHULUAN}

Sekarang ini kita memasuki Revolusi Industri keempat atau sering disebut dengan Industri 4.0. Inti dari Revolusi Industri 4.0 adalah digitalisasi pada hampir keseluruhan proses bisnis (digital economy, artificial intelligence, big data, robotic) dan kebutuhan jumlah Sumber Daya Manusia serta tuntutan keterampilannya. Revolusi Industri 4.0 tidak mungkin bisa untuk dihindari apalagi dicegah. Dampak positif yang bisa di dapatkan adalah efisiensi, efektifitas, dan simplifikasi proses bisnis secara besar-besaran pada hampir seluruh sektor industri tanpa kecuali. Industry 4.0 menghadirkan ancaman besar terhadap proses bisnis konvensional sekaligus menghadirkan peluang besar terhadap bisnis berbasis digital termasuk peluang besar kesempatan kerja (Sururi, 2019). Kehadiran Revolusi Industri 4.0 membawa perubahan pada penyesuaian pekerjaan manusia, mesin, teknologi dan proses di berbagai bidang profesi termasuk profesi akuntan. Banyak perusahaan besar telah mengembangkan teknologi ini, karena didukung oleh standarisasi atas proses pengelolaan keuangan, standarisasi atas arsitektur sistem dan informasi (standardization of financial processes, systems, dan information architecture). Profesi akuntansi sering diasosiasikan dengan komputer dan pekerjaan dengan penggunaan teknologi (Akhter \& Sultana, 2018).

Menurut penelitian di Bangladesh, profesi akuntan diperkirakan akan menghilang pada beberapa tahun ke depan, dimana aktivitas 
akuntansi digantikan dengan teknologi automasi yang menyebabkan pemutusan kerja akuntan (Frey \& Osborne, 2018). Pada tahun 2015, Boston Consulting Group (BCG) melaporkan prediksi bahwa sepertiga pekerjaan manual akan dieliminasi digantikan oleh artificial intellegence pada tahun 2025. PrincewaterCoopers pada tahun 2018, menganalisa 20.000 pekerjaan dari 29 negara yang mempunyai resiko potensial dikarenakan adanya automasi 20 tahun mendatang (Akhter \& Sultana, 2018). Potensi teknologi menggantikan peran profesi akuntan hanya menunggu waktu. Peran akuntan akan bersifat strategis dan konsultatif. Maka dari itu akuntan perlu memiliki sertifikasi supaya mampu bertahan dalam bersaing. Seorang akuntan juga harus memiliki strategi diantaranya penguasaan soft skill baik interpersonal skills maupun intra personal skills, business understanding skills dan technical skills agar mampu menja wab tantangan di era digital ini. Hal ini mengakibatkan profesi akuntan underestimate terkait dampak teknologi terhadap pekerjaan akuntan. Ini menjadikan tantangan berat yang harus dianalisa lebih lanjut (Kompasiana, 2019). Penelitian ini mencoba untuk mengevaluasi kebutuhan pendidikan, efek IoT, kesempatan dan tantangan yang dihadapi oleh akuntan profesional.

\section{TINJAUAN PUSTAKA}

\section{Sejarah Singkat Revolusi Industri}

Revolusi industri yang dimulai di Inggris lebih dari dua abad lampau, membawa dunia menuju modernisasi yang kita kenal hari ini. Revolusi itu pula yang menciptakan tatanan ekonomi yang telah membawa perubahan mendasar pada strata kehidupan sosial secara global. Revolusi industri itu disebut-sebut sebagai milestone perpindahan dari middle age ke era modern, mengikuti jejakjejak zaman reneissance. Penemuan mesin uap oleh James Watt telah memicu penemuanpenemuan lain yang hakikatnya ditujukan untuk mempermudah berbagai proses, mulai dari proses manufaktur, distribusi, pertanian, pertambangan, hingga pembangunan infrastruktur. Jika revolusi industri abad ke-18 atau sekitar tahun 1800-an itu bisa kita sebut Revolusi Industri 1.0, maka Revolusi Industri 2.0 atau sekitar tahun 1900-an terjadi pada era penemuan listrik dan assembly line yang meningkatkan produksi barang. Gejolak modernisasi model baru ini berlanjut dengan penemuan internet, teknologi informasi, komersialisasi personal computer yang memicu lahirnya Revolusi Industri 3.0 sekitar tahun 2000an. Lalu Revolusi Industri 4.0 dengan digital economy sebagai platform global yang mengubah tatanan sosial dan ekonomi dunia. Penemuan internet, yang dilanjutkan dengan IoT, big data, bio \& nano technology, hingga artificial intelligence menjadi artefak sebagai bukti perubahan besar itu telah tiba. Revolusi industri berhasil meredefinisi aspek speed, capacity, dan eficiency dalam sistem ekonomi modern. Sektor bisnis dan industri bukanlah satu-satunya yang akan mengalami perubahan masif di era IoT. Namun harus diakui sektor ini telah menjadi leader perubahan dalam beberapa dekade terakhir. Kesiapan untuk memasuki era IoT dan artificial intelligence mau tidak mau dipicu oleh kesiapan SDM, infrastruktur, teknologi, dan governance sebuah suatu komunitas (IAI, 2019). Fase periode revolusi industri membutuhkan masa yang semakin singkat dari waktu ke waktu. Saat ini berbagai macam kebutuhan manusia telah banyak menerapkan dukungan internet dan dunia digital sebagai wahana interaksi dan transaksi, misal dalam hal marketplace (Buka Lapak, Tokopedia), sharing economy (BookMooch, carpooling.com), e-Education (Canvas Network, Iversity), smart appliances, smart city, $e$ Government, smart manufacturing (3D printing, sculpteo), one health services (HealthTap, klikDOKTER.com), cloud collaborative (dropbox, MicrosoftOffice365, GoogleDrive).

\section{Komputerisasi dan Otomatisasi}

Menurut Akhter \& Sultana (2018), "automation is a process which follows preprogrammed 'rules' for completing accounting and auditing process". Software digunakan untuk proses otomatisasi akuntansi seperti dalam proses transaksi, penggajian, piutang, implementasi internal kontrol dengan tujuan untuk mengurangi resiko hilangnya dokumen, membantu mendeteksi fraud, dan paperless invoicing. Berdasarkan hasil penelitian $\mathrm{PwC}$, bahwa digitalisasi di negara-negara Asia Pasific (termasuk didalamnya Indonesia) diperkirakan akan mengalami peningkatan cukup signifikan naik sebesar $31 \%$ dari $36 \%$ pada tahun 2014 menjadi $67 \%$ pada tahun 2020 (PriceWaterhouseCoopers, 2016). Accountants \& Accountants (2013) menyatakan bahwa muncul tantangan dan kesempatan baru akibat penggunaan teknologi dapat berimbas pada profesi akuntansi. Menurut penelitian Frey \& 
Osborne (2018), prediksi probabilitas efek dari berikut:

otomatisasi untuk beberapa profesi adalah sebagai

Tabel 1

Prediksi Efek Otomatisasi Terhadap Profesi

\begin{tabular}{ll}
\hline \multicolumn{1}{c}{ Profesi } & \multicolumn{1}{c}{ Level Resiko } \\
\hline Manajer Sumber Daya Manusia & Sangat Rendah \\
Manajer Pemasaran & Sangat Rendah \\
Manajer Keuangan & Rendah \\
HRD, Training, dan lainnya & Rendah \\
Customer Service Representatives & Sedang \\
Pembukuan, Akunting, Auditing Clerks & Tinggi \\
Pemeriksa Pajak, Kolektor Pajak & Tinggi \\
Analis Anggaran & Tinggi \\
Akuntan dan Auditor & Tinggi \\
Penggajian & Sangat Tinggi \\
Petugas Pinjaman & Sangat Tinggi \\
Teller & Sangat Tinggi \\
Pembuat Laporan Pajak & Sangat Tinggi \\
\hline
\end{tabular}

Sumber: (Frey \& Osborne, 2018)

Karakteristik utama industri 4.0 adalah kehadiran disruptive technology yang begitu cepat dan pesat sehingga memberi ancaman bagi industri-industri raksasa dan perubahan ukuran perusahaan dimana sekarang ini ukuran perusahaan tidak perlu besar, namun perusahaan tersebut haruslah 'lincah' dalam memanfaatkan teknologi dan informasi. Berikut beberapa contoh jenis level pekerjaan yang mulai tergantikan karena otomatisasi (Akhter \& Sultana, 2018):

Pemrosesan data, analisa dan pemenuhan aktivitas dilakukan oleh software. Portals, esignature tools, document manager, workflow tools dan client server blogs merupakan contoh otomatisasi dalam hal pemrosesan data.

Pengecekan digital. Penggunaan PDF sebagai contoh dapat digunakan untuk mencari akun konsumen secara cepat.

Sejak 2015 untuk proses audit, KPMG menggunakan McLaren Applied Technologies (MAT) dalam menganalisa data tidak terstruktur. Deloitte menggunakan Kira untuk divisi konsultasi.

Masyarakat mulai menggunakan mobile accounting untuk mendapatkan data real time.

Penggunaan Financial Process Automation (FPA) untuk pembayaran, menerbitkan faktur, pengecekan excel.

Sejak 2013 Securities\&Exchange Commission menggunakan "RoboCop" sebagai alat analisis audit dan sekuritas, PwC menggunakan RON.
Artificial Intelligence (misalnya Alex, Cartana, Siri) yang dapat mengelompokkan akun dan melaporkan pajak.

Di sisi lain industri 4.0 membawa perubahan positif ke dalam lingkungan akuntansi antara lain kualitas data yang lebih baik, mengurangi greenwash dan brownwash, kredibilitas data yang lebih tinggi, tranparan (Burritt \& Christ, 2016), digital real-time data (Seele, 2016). Namun menurut Nagy, Oláh, Erdei, Máté, \& Popp (2018) terdapat beberapa faktor yang menjadi penghalang (obstructing factors) perkembangan Industri 4.0 sebagai berikut:

Faktor Pasar; Ketidakpercayaan, Ketidakpastian, Penilaian realistik atas kemampuan organisasi, Kurangnya permintaan atas pembelajaran berkelanjutan, Faktor Tenaga Kerja, Tenaga kerja berkualitas kurang memadai, Kurangnya tenaga kerja,Pelatihan tradisional

Faktor Organisasi; Kurangnya strategi digital, Investasi beresiko, Ketakutan atas kehilangan aset intelektual, Patner tidak memiliki teknologi, Kegagalan pengembangan database, Kurangnya dukungan dari manajemen senior

Faktor Teknologi; Mahalnya teknologi, Kurangnya standar, Keamanan data, Analisis data yang kurang

Menurut Akhter \& Sultana (2018), teknologi masa depan yang dapat mendukung otomatisasi akuntansi antara lain dalam hal tax agent, optical character recognition, auditing practice, cloud 
technology, blockchain (merubah penilaian ekonomi dari aset, rekonsiliasi pembukuan tidak diperlukan lagi), barcode system, robo advice scene, databank of advice, IoT, machine learning, auditing of expense submissions, clear invoice payments, bank reconciliation, dan risk assessment. Dengan adanya teknologi tersebut, mengakibatkan terjadinya perubahan arah kegiatan profesi akuntansi seperti dapat dilihat pada tabel dibawah ini.

Tabel 2

Perubahan Kegiatan Profesi Akuntansi

\begin{tabular}{|c|c|c|c|}
\hline Activities & Masa Lampau & Sekarang & Masa Depan \\
\hline Entry data & Akuntan & Operator/ akuntan & Artificial Intelligence (AI) \\
\hline Pembukuan & Akuntan & Software & Software/ AI \\
\hline Compliance Work & Akuntan/ auditor & Software & AI \\
\hline $\begin{array}{l}\text { Mengambil dokumen dari } \\
\text { klien }\end{array}$ & Staf akunting & $\begin{array}{l}\text { Dokumen elektronik melalui } \\
\text { email }\end{array}$ & $\begin{array}{l}\text { Dokumen elektronik melalui } \\
\text { email }\end{array}$ \\
\hline $\begin{array}{l}\text { Menyiapkan tagihan dan } \\
\text { daftar permintaan }\end{array}$ & Akuntan & $\begin{array}{l}\text { Software billing, purchase } \\
\text { requisition software }\end{array}$ & Machine Learning \\
\hline Menyiapkan buku besar & Akuntan & Spread Sheet & Software \\
\hline Rekonsiliasi penerimaan & $\begin{array}{l}\text { Akuntan memerlukan } \\
\text { "balance the checkbook" }\end{array}$ & Software & Machine-readable data \\
\hline Investigasi audit & Auditor & $\begin{array}{l}\text { Menggunakan software } \\
\text { untuk analisis forensik }\end{array}$ & AI \\
\hline $\begin{array}{l}\text { Menyiapkan dokumen pajak } \\
\text { dan perhitungannya }\end{array}$ & Akuntan & Software & $\begin{array}{l}\text { Machine Learning } \\
\text { Algorithm }\end{array}$ \\
\hline $\begin{array}{l}\text { Menyiapkan Laporan } \\
\text { Keuangan }\end{array}$ & Akuntan & $\begin{array}{l}\text { Akuntan dengan bantuan } \\
\text { ERP, SAP software }\end{array}$ & $\begin{array}{l}\text { XBLR (automated annual } \\
\text { reports) }\end{array}$ \\
\hline
\end{tabular}

Sumber: (Akhter \& Sultana, 2018)

Perusahaan yang melakukan investasi digital diharapkan dapat memperoleh ROI (Return On Investment) dalam waktu yang relatif cepat yaitu sebesar 55\% kurang dari 2 (dua) tahun (PriceWaterhouseCoopers, 2016). Dalam penelitian Gubbi, Buyya, Marusic, \& Palaniswami (2013), penggunaan teknologi dalam menyelesaikan pekerjaan yang berulang (monoton) secara signifikan dapat mengurangi biaya produksi. Hal tersebut juga sejalan dengan hasil penelitian Agbor (2011) yang menyatakan bahwa penggunaan teknologi (electronic services) untuk pelayanan di perbankan akan mengurangi pengeluaran biaya. Sedangkan dari sisi konsumen, penggunaan teknologi dapat membantu memudahkan dan mempercepat kebutuhan pelayanan keuangan tanpa kendala seperti yang dialami apabila menggunakan pelayanan tradisional bank (Kumar, 2006).

\section{Ikatan Akuntan Indonesia (IAI) Sebagai Wadah Profesi Akuntan Profesional}

Menurut Burritt \& Christ (2016), ada empat langkah utama akuntan profesional dalam menghadapi industri 4.0 yaitu sebagai berikut:

Awareness; Menjadi aware terhadap perkembangan revolusi industri 4.0 dengan melihat kesempatan yang akan muncul, Menyadari potensi perkembangan bisnis baru (misal di Jerman 80\% perusahaan memiliki rencana untuk menghadapi revolusi industri 4.0, di China $60 \%$ perusahaan memiliki building knowledge, kebanyakan negara telah berada pada tahap awal diseminasi informasi)

Education; Memberi tekanan pada institusi pendidikan untuk membuat kurikulum yang relevan bagi mahasiswa akuntansi untuk menyesuaikan dengan konektivitas digital, Mengadakan pelatihan seperti manajemen informasi dalam shared platforms, keperluan realtime accounting pada stakeholders.

Profesional Development; Meningkatkan kinerja organisasi profesi beserta programprogram pengembangan profesionalnya.

Reaching Out; Akuntan memiliki kontrol yang kurang atas data, Lingkungan transdisciplinary mix of advisers (misalnya environmental accounting sangat bergantung pada informasi fisik yang diperoleh dibawah tanggung jawab para teknisi. Konektivitas antara teknisi dan akuntan harus terbangun agar informasi akuntansi dapat terjaga dengan baik). 
Secara tidak langsung revolusi industri 4.0 berimbas terhadap profesi akuntan. Oleh sebab itu untuk menjamin keberlanjutan profesi akuntan di masa depan yang penuh dengan disrupsi bisnis dan perubahan landskap ekonomi global, IAI menyusun Program Prakarsa 6.1: Meneguhkan Kejayaan Akuntan Profesional, salah satu yang menjadi acuan bagi profesi akuntan profesional adalah sebagai berikut:

Tabel 3

Tren Makro dan Implikasi Bagi Profesi Akuntan dari Segi Lingkungan Profesi sebagai berikut:

\begin{tabular}{|c|c|}
\hline Tren Makro & Implikasi Bagi Profesi \\
\hline $\begin{array}{l}\text { Rentang stabilitas yang semakin pendek dan tidak } \\
\text { berkesinambungan dalam digital ekonomi, bisnis, politik, } \\
\text { kewarganegaraan, meningkatkan kebutuhan akan fleksibilitas } \\
\text { profesi. } \\
\text { Transparansi dan akuntabilitas di sektor publik: peningkatan } \\
\text { pengawasan keuangan publik dan tuntutan atas informasi yang } \\
\text { transparan, lengkap, dan akurat dalam proses pengambilan } \\
\text { keputusan. } \\
\text { Publik semakin tidak menoleransi aksi-aksi korupsi, fraud, } \\
\text { pencucian uang, dan praktik tidak beretika lainnya di berbagai } \\
\text { sektor. }\end{array}$ & $\begin{array}{l}\text { CFO dan Akuntan Profesional dituntut memproyeksikan imbal hasil } \\
\text { yang lebih besar bagi organisasi. Kapabilitas Akuntan } \\
\text { Profesional akan meningkat ke berbagai aspek pengambilan } \\
\text { keputusan, dari strategi hingga mendefinisikan model bisnis. } \\
\text { Meningkatkan ekspektasi publik agar Akuntan Profesional dan } \\
\text { profesi memainkan peran yang lebih besar dalam membangun } \\
\text { tata kelola dalam mengantisipasi korupsi, fraud, pencucian } \\
\text { uang, atau praktik tidak beretika lainnya. } \\
\text { Pemerintah dituntut untuk meningkatkan transparansi dan } \\
\text { akuntabilitas, akan meningkatkan kebutuhan akan pelaporan } \\
\text { keuangan. } \\
\text { Pelaporan akan membutuhkan sudut pandang yang holistik terhadap } \\
\text { performa dan masa depan entitas, dan nilai-nilai Akuntan } \\
\text { Profesional akan sangat bergantung pada kemampuannya untuk } \\
\text { membangun perspektif itu. } \\
\text { Akuntan Profesional di masa depan perlu dilengkapi dengan } \\
\text { semangat entrepreneurship, kreativitas, dan kemampuan untuk } \\
\text { berpikir strategis. Profesi menghadapi tantangan yang makin } \\
\text { besar untuk menarik talenta-talenta terbaik bergabung di profesi } \\
\text { akuntan. } \\
\text { Berkembangnya pendapat negatif tentang anggota profesi yang } \\
\text { memberikan jasa tidak benar kepada klien, misalnya terkait tax } \\
\text { planning dan creative accounting. }\end{array}$ \\
\hline
\end{tabular}

Sumber: Prakarsa 6.0 IAI (2019)

Tabel 4

Tren Makro dan Implikasi Bagi Profesi Akuntan dari Segi Teknologi Informasi sebagai berikut:

\begin{tabular}{|c|c|}
\hline Tren Makro & Implikasi Bagi Profesi \\
\hline $\begin{array}{c}\text { Teknologi Informasi (TI) seperti artificial intelligence, } \\
\text { blockchain, cloud, big data, internet of things, robotic, } \\
\text { telah mendisrupsi tatanan ekonomi konvensional } \\
\text { sekaligus menghadirkan model bisnis baru. }\end{array}$ & $\begin{array}{c}\text { Akuntan Profesional harus menjaga relevansinya dengan } \\
\text { meningkatkan kompetensi untuk membantu klien } \\
\text { dan pengusaha menghadapi kecepatan perubahan dan } \\
\text { inovasi karena perkambangan TI. }\end{array}$ \\
$\begin{array}{c}\text { Seiring dengan penggunaan sistem cerdas, penggalian } \\
\text { data, dan analisa prediktif dalam mengeksploitasi big }\end{array}$ \\
data yang akan mengubah operasionalisasi dan \\
interpretasi berbagai aspek akuntansi, keamanan \\
siber akan menjadi resiko utama yang harus dikelola. \\
Fungsi teknis akuntan yang bersifat repetitif dan analitik \\
akan digantikan oleh komputer dan artificial intelli- \\
gence.
\end{tabular}

Sumber: Prakarsa 6.0 IAI (2019)

\section{III.METODE}

Penelitian ini bersifat kualitatif dengan fokus pada pengumpulan data melalui survey terhadap 6 (enam) Kantor Jasa Akuntan (KJA) yang berdomisili di Provinsi Kepulauan Riau dan yang mendapatkan Izin dari Kementerian Keuangan Republik Indonesia (Sekretariat Jenderal Pusat Pembinaan Profesi Keuangan) Per 12 September 2018. Daftar KJA resmi di Provinsi Kepulauan Riau yang menjadi sampel dalam penelitian dapat dilihat pada Tabel 8 (lampiran). KJA dipilih sebagai sampel dalam penelitian ini dengan asumsi bahwa KJA merupakan salah satu profesi akuntansi profesional dimana semua level pekerjaannya berdasarkan ilmu akuntansi (Akhter \& Sultana, 2018). Selain itu KJA merupakan perusahaan yang mengalami tantangan dan mendapatkan kesempatan dari perubahan teknologi (Islam, 2017). Survey berupa pertanyaan terbuka, pilihan jawaban dan pertanyaan dengan skala (Nagy et al., 2018). 


\begin{abstract}
Pertanyaan terbuka mengumpulkan data mengenai jumlah karyawan, tahun berdiri KJA, saran owner dan sebagainya. Pilihan jawaban untuk mengumpulkan data mengenai pilihan KJA. Pertanyaan dengan menggunakan skala dipakai untuk mengumpulkan data pendapat. Literatur dan hasil dari penelitian terdahulu dikumpulkan sebagai informasi gambaran umum. Untuk mendukung penelitian ini, peneliti membuat kuesioner dan melakukan percakapan melalui whatsapp dengan pemilik KJA. Penelitian ini mencoba untuk mencari jawaban atas pertanyaan-pertanyaan yang berhubungan dengan revolusi industri 4.0 sebagai berikut: Bagaimana tren pendidikan yang mengisi pekerjaan
\end{abstract}

akuntansi?, Bagaimana efek dari IoT terhadap tenaga kerja akuntan profesional?, Bagaimana kesempatan dan tantangan yang dihadapi oleh akuntan profesional?

\section{IV.HASIL PENELITIAN DAN PEMBAHASAN}

Pertanyaan pertama: "Bagaimana tren pendidikan yang mengisi pekerjaan akuntansi?”

Berikut hasil survey KJA Terdaftar di Wilayah Kepulauan Riau mengenai banyaknya software yang digunakan dalam penyelesaian pekerjaan dan latar belakang Pendidikan Karyawan:

Tabel 5

Penggunaan Software dan Latar Belakang Pendidikan Karyawan

\begin{tabular}{lll}
\hline Nama KJA & $\begin{array}{l}\text { Software yang } \\
\text { Digunakan (jenis) }\end{array}$ & $\begin{array}{l}\text { Karyawan dengan } \\
\text { Pendidikan } \\
\text { Akuntansi }\end{array}$ \\
\hline $\begin{array}{l}\text { KJA FETRI. SE. AK.MM. BKP. } \\
\text { CA. ACPA }\end{array}$ & 5 & $\ddot{\mathrm{u}}$ \\
KJA Juhli Edi Simanjuntak & 2 & $\ddot{\mathrm{u}}$ \\
$\begin{array}{l}\text { KJA Lilis Susanti } \\
\text { PT AKUNTAN MANDIRI SE- }\end{array}$ & 5 & $\ddot{\mathrm{u}}$ \\
$\begin{array}{l}\text { JATI } \\
\text { Sembilan Sembilan Cahaya Les- } \\
\text { tari }\end{array}$ & 2 & $\ddot{\mathrm{u}}$ \\
\hline
\end{tabular}

Sumber: Data Diolah (2019)

Dengan rata-rata usia berdiri KJA adalah 3 (tiga) tahun, banyaknya software yang digunakan dalam menyelesaikan pekerjaan ada 2 (dua) KJA yang menggunakan lima macam software, dengan rata-rata yang lain menggunakan dua macam software. Sedangkan semua karyawan di KJA adalah lulusan atau mahasiswa sedang kuliah dengan jurusan yang linier dengan bidang pekerjaan (dapat dilihat pada tabel 5).

Yang menarik dari hasil survey KJA adalah

Tabel 6

Prosentase Jumlah Karyawan Tiap Jenjang Pendidikan

\begin{tabular}{ll}
\hline Tingkat Pendidikan Karyawan & Prosentase \\
\hline Lulusan SMU/ SMK & $20 \%$ \\
Sedang Kuliah & $60 \%$ \\
D3 & $40 \%$ \\
D4 & $0 \%$ \\
S1 & $80 \%$ \\
S2 dan/ S3 & $40 \%$ \\
\hline
\end{tabular}

Sumber: Data Diolah (2019) 
bahwa lulusan Diploma 4 (D4) Akuntansi masih belum mengisi tenaga kerja di KJA (prosentasenya $0 \%$ ), dan yang paling tinggi adalah penyerapan untuk Strata 1 sebanyak $80 \%$. Padahal menurut Sururi (2019), pendidikan vokasi akuntansi mencakup kompetensi analitis, adaptasi, kerjasama, interpersonal, manajerial, berorganisasi, taktis dan operasional. Di Indonesia masih banyak perusahaan yang mempekerjakan pendidikan jalur non vokasi.

Pertanyaan kedua: "Bagaimana efek dari IoT terhadap tenaga kerja akuntan profesional?"

Berdasarkan survey, sebesar 60\% KJA merasa bahwa penggunaan IoT dan software membawa dampak terhadap pengurangan penggunaan tenaga kerja profesional akuntansi. Sebesar $60 \%$ KJA menggunakan $70-100 \%$ total waktu menyelesaikan pekerjaan menggunakan komputer (software) dan internet dibandingkan dengan pengerjaan manual (kurang dari 30\% total waktu penyelesaian pekerjaan). Dan sisanya sebesar $40 \%$ KJA menggunakan komputer dan internet sebanyak $51-75 \%$ dari total waktu penyelesaian pekerjaan dibandingkan dengan pengerjaan manual (kurang dari 50\% dari total waktu penyelesaian). Hasil ini mengindikasikan bahwa sebagian besar KJA sudah mulai menggunakan software dan IoT dibandingkan dengan tenaga kerja manual. Hal ini dapat menimbulkan masalah apabila setiap lulusan akuntansi tidak dibekali dengan softskill tentang software dan teknologi. Mereka akan tergilas oleh kemajuan teknologi atau AI yang dapat menggantikan kemampuan manusia.

Ada beberapa aktivitas akuntansi yang dapat dilakukan oleh tenaga kerja profesional (akuntan), software, dan teknologi AI. Berikut disajikan prosentase pengerjaan aktivitas akuntansi per subjek:

Tabel 7

Besarnya aktivitas akuntansi dan subjek pelaku di KJA Wilayah Kepri

\begin{tabular}{|c|c|c|}
\hline Aktivitas & Subjek/ Pelaku & $\begin{array}{l}\text { Prosentase Pengerjaan oleh } \\
\text { Subjek (dalam \%) }\end{array}$ \\
\hline \multirow{3}{*}{ Data entry } & Akuntan & 0 \\
\hline & Operator/ Akuntan & 100 \\
\hline & Software/ AI & 0 \\
\hline \multirow{3}{*}{ Penjurnalan } & Akuntan & 60 \\
\hline & Software & 80 \\
\hline & AI (Artificial Intelligence) & 0 \\
\hline \multirow{3}{*}{ Pekerjaan Kepatuhan } & Akuntan/ Auditor & 100 \\
\hline & Software & 20 \\
\hline & AI & 0 \\
\hline \multirow{2}{*}{ Mengambil dokumen klien } & Staf Akunting & 60 \\
\hline & Email (electronic document) & 100 \\
\hline \multirow{3}{*}{$\begin{array}{l}\text { Mempersiapkan tagihan dan } \\
\text { permintaan barang }\end{array}$} & Akuntan & 100 \\
\hline & Software & 40 \\
\hline & Akuntan & 40 \\
\hline \multirow[t]{2}{*}{ Mempersiapkan buku besar } & Spread Sheet & 20 \\
\hline & Software & 80 \\
\hline \multirow{3}{*}{ Rekonsiliasi } & Akuntan & 80 \\
\hline & Software & 60 \\
\hline & Auditor & 80 \\
\hline \multirow[t]{2}{*}{ Investigasi Personal Dalam Audit } & Software in forensic analysis & 60 \\
\hline & AI & 0 \\
\hline \multirow{3}{*}{$\begin{array}{l}\text { Menyiapkan dokumen pajak dan } \\
\text { perhitungan }\end{array}$} & Akuntan & 100 \\
\hline & Software & 60 \\
\hline & Machine Learning Algorithm & 0 \\
\hline \multirow{3}{*}{ Menyiapkan Laporan Keuangan } & Akuntan & 100 \\
\hline & Software & 60 \\
\hline & Automated Annual Report & 0 \\
\hline
\end{tabular}

Dari tabel diatas, dapat disimpulkan bahwa ada tiga jenis aktivitas yang memiliki prosentase tertinggi dalam penggunaan software dibandingkan tenaga kerja manual yaitu penjurnalan $(60 \%$ dilakukan oleh akuntan dan
$80 \%$ pengerjaan penjurnalan menggunakan software), mengambil dokumen klien (100\% menggunakan email dan $60 \%$ diambil oleh staf akunting), dan mempersiapkan buku besar (80\% dilakukan menggunakan software, $40 \%$ oleh 
akuntan, dan 20\% menggunakan spread sheet).

Sedangkan ada tujuh jenis aktivitas yang memiliki prosentase tertinggi dalam penggunaan tenaga profesional (akuntan) antara lain data entry (100\% dilakukan oleh operator/ akuntan), pekerjaan kepatuhan $(100 \%$ dilakukan oleh akuntan/ auditor dan hanya $20 \%$ dilakukan oleh software), mempersiapkan tagihan dan permintaan barang $(100 \%$ masih dilakukan oleh akuntan dan $40 \%$ dilakukan melalui software), rekonsiliasi $(80 \%$ dilakukan oleh akuntan dan $60 \%$ dikerjakan oleh software), investigasi personal dalam audit ( $80 \%$ dilakukan oleh auditor langsung dan $60 \%$ dikerjakan oleh software inforensic analysis), menyiapkan dokumen pajak dan perhitungannya $(100 \%$ dikerjakan oleh akuntan dan $60 \%$ dikerjakan oleh software), dan menyiapkan Laporan Keuangan $(100 \%$ oleh akuntan dan $60 \%$ dilakukan oleh software). Dengan kata lain, masih lebih banyak jenis pekerjaan akuntansi yang masih mempercayakan menggunakan lebih banyak tenaga kerja profesional ketimbang dikerjakan oleh software.

Pertanyaan ketiga: "Bagaimana kesempatan dan tantangan yang dihadapi oleh akuntan profesional?"

Berdasarkan hasil survey, softskill yang dibutuhkan oleh KJA untuk akuntan profesional adalah memiliki kemampuan berpikir kritis dan analitis (sebesar 100\% KJA), memiliki kemampuan komunikasi yang baik (sebesar 40\% KJA), dan memiliki kemampuan entry data (sebesar 20\% KJA).

Dalam menghadapi revolusi 4.0, akuntan profesional mengalami perubahan peran dimana yang dahulu sebagai data entry menjadi jasa konsultasi dan big data analysis (sebagai contoh menyediakan sumber baru data non finansial, membantu keputusan khusus dan menyediakan penilaian, serta menyediakan hard evidence). Seorang akuntan profesional (CA/ Chartered Accountant atau CPA Chartered Public Accountant) harus meningkatkan pengetahuan akan teknologi terutama software, AI dan sebagainya, disamping juga harus memperhatikan aspek cyber security seperti kontrol yang baru pada detection, response, dan resilience, pendekatan eksternal yang dinamis (Akhter \& Sultana, 2018).

Semisal dalam dunia perbankan dipercaya bahwa teknologi akan mengurangi banyak jenis pekerjaan, tetapi sebenarnya bank mempunyai kesempatan dalam mengakses bisnis baru, menciptakan kesempatan pekerjaan baru misalnya dalam hal teknologi informasi dan teknologi keamanan data (Nagy et al., 2018).

Menurut survey Half (2018), sesuai dengan Laporan dari US Bureau of Labor Statistics, angka pengangguran akuntan di Amerika Serikat mengalami penurunan yaitu dari $4.2 \%$ pada tahun 2011 dibandingkan pada tahun 2018 sebesar $1.8 \%$. Hal ini bisa menjadi sedikit pengharapan bagi akuntan di Indonesia khususnya, mengingat area akuntansi di era revolusi 4.0 bersifat global.

\section{SIMPULAN}

Berdasarkan hasil dari penelitian ini, didapatkan bahwa penggunaan tenaga kerja akuntan profesional masih cukup tinggi yakni 80\% merupakan Sarjana Akuntansi. Penggunaan IoT pada penyelesaian pekerjaan adalah sebesar $60 \%$ KJA menggunakan $70-100 \%$ dari total waktu pengerjaan pekerjaan menggunakan komputer dan internet (IoT). Selain itu, penelitian ini menghasilkan kesimpulan bahwa softskill dalam hal kemampuan berpikir kritis dan analitis lah yang menjadi softskill tertinggi yang dibutuhkan KJA.

Penelitian ini memberikan kontribusi dalam menyediakan bukti penggunaan IoT pada area pekerjaan akuntan profesional dan sebagai bahan benchmark antar KJA. Perubahan skill dibutuhkan agar SDM tetap relevan dengan perkembangan teknologi kedepannya.

Tidak ada jaminan model ekonomi yang sekarang bertransformasi menjadi digital ekonomi, akan tetap menjadi mainstream ekonomi masa depan. Ketika model bisnis dan perekonomian bertransformasi sedemikian rupa, tidak ada jaminan bahwa profesi akuntan akan tetap eksis dan relevan di masa depan. Karena itu, profesi akuntansi dituntut melakukan peningkatan keahlian untuk membuat kita tetap berada di pusaran aktivitas ekonomi digital di masa depan. Sehingga apa yang dikatakan Hawking (2015) bahwa "Computers will overtake humans with AI at some within the next 100 years. When that happens, we need to make sure the computers have goals aligned with ours" dapat kita jembatani dan kita persiapkan. Hanya ada dua pilihan bagaimana menghadapi era digital economy, menjadi pemain dan terlibat mengambil keuntungan darinya, atau menjadi korban, pasar, dan hanya sebatas objek penderita dalam interaksi global yang tanpa batas ini (IAI, 2019). 
Rekomendasi (saran) bagi penelitian lebih lanjut adalah dengan menambahkan jumlah KJA atau akuntan profesional di wilayah yang lebih luas atau bahkan di luar Indonesia, sehingga data yang diolah lebih signifikan. Topik dari penelitian ini sangatlah luas, tetapi hasil dari penelitian ini tidak dapat secara mutlak untuk digeneralisasikan, karena sampel yang digunakan terbatas.

\section{DAFTAR PUSTAKA}

Accountants, A. O. C. C., \& Accountants, I. of M. (2013). Digital Darwinism: Thriving in the face of technology change. Acca, 1-64. Retrieved from http://www.accaglobal.com/content/dam/acca/global/ PDF-technical/futures/pol-afa-tt2.pdf

Agbor, J. M. (2011). The Relationship between Customer Satisfaction and Service Quality: A Study of Three Service Sectors in Umeå. Middle Eastern Finance and Economics, 4(3), 92. https://doi.org/10.1017/ CBO9781107415324.004

Akhter, A., \& Sultana, R. (2018). Sustainability of Accounting Profession at the Age of Fourth Industrial Revolution. International Journal of Accounting and Financial Reporting, 8(4), 139. https://doi.org/10.5296/ijafr.v8i4.13689

Burritt, R., \& Christ, K. (2016). Industry 4.0 and environmental accounting: a new revolution? Asian Journal of Sustainability and Social Responsibility, 1 (1), 23-38. https://doi.org/10.1186/s41180-016-0007 $-\mathrm{y}$

Frey, C. B., \& Osborne, M. A. (2018). The Future of Unemployment. Constructing Unemployment, 233241. https://doi.org/10.4324/9781351161329-10

Goh, C., Seow, P. S., \& Pan, G. (2017). Automation and the Accounting profession. Institute of Singapore Chartered Accountants Journal. Diambil dari: http://ink.library.smu.edu.sg/soa_research/1640.

Gubbi, J., Buyya, R., Marusic, S., \& Palaniswami, M. (2013). Internet of Things (IoT): A vision, architectural elements, and future directions. Future Generation Computer Systems, 29(7), 1645-1660. https://doi.org/10.1016/j.future.2013.01.010

Half, Robert. (2018). Hiring Report: Low Unemployment Rates for Financial Professionals. Diambil dari: https://www.roberthalf.com/blog/evaluating-jobcandidates/hiring-report-low-unemployment-ratesfor-financial-professionals.

Hawking, S. (2015). Google Zeitgeist 2015. London. Diambil dari: https://www.youtube.com/watch? $\mathrm{v}=$ IBfwgHLLPfs.

Ikatan Akuntan Indonesia (IAI). (2019). Prakarsa 6.1: Langkah ke Depan Akuntan Indonesia di Usia yang ke 61 IAI, Menguasai Perubahan, Menyiapkan Masa Depan, Meneguhkan Kejayaan Akuntan Profesional Negeri. Jakarta.

Institute of Singapore Chartered Accountants (ISCA) and the Institute of Chartered Accountants in England and Wales (ICAEW). (2017). Our Future Together: Industry Perspectives on the Future of Professional Learning and Entrepreneurship. ISCA and ICAEW.
Diambil dari: https://isca.org.sg/tkc/our-futuretogether/publications/publications/2017/may/ industry-perspectives-future-of-professional-learning -and-entrepreneurship.

Islam, Muhammad Azizul. (2017). Future of Accounting Profession: Three Major Changes and Implications for Teaching and Research. International Federation of Accountants. Diambil dari: https://www.ifac.org/ global-knowledge-gateway/business-reporting/ discussion/future-accounting-profession-three-major

Kemenristekdikti. (2018). Menristekdikti: Profesi Akuntan Harus Beradaptasi Dengan Revolusi Industri 4.0. Diambil dari https://ristekdikti.go.id/kabar/ menristekdikti-profesi-akuntan-harus-beradaptasidengan-revolusi-industri-4-0.

Kompasiana. (2019). Akuntansi di Era Revolusi Industri 4.0. Diambil dari https://www.kompasiana.com/ lizazu/5c2c296c12ae940f8754b280/akuntansi-di-erarevolusi-industri-4-0.

Kumar, V., \& Reinartz, W. J. (2006). Customer relationship management: A databased approach. Hoboken, NJ: Wiley.

Nagy, J., Oláh, J., Erdei, E., Máté, D., \& Popp, J. (2018). The role and impact of industry 4.0 and the internet of things on the business strategy of the value chainthe case of hungary. Sustainability (Switzerland), 10 (10). https://doi.org/10.3390/su10103491

PriceWaterhouseCoopers. (2016). 2016 Global Industry 4.0 Survey Industry 4.0 : Building the digital enterprise. Pwc.Com, 1-36. https://doi.org/www.pwc.com/gx/ en/industries/industrial-manufacturing/publications/ assets/pwc-building-digital- enterprise.pdf.

Seele, P. (2016). Digitally unified reporting: how XBRLbased real-time transparency helps in combining integrated sustainability reporting and performance control. Journal of Cleaner Production, 136, 65-77. https://doi.org/10.1016/j.jclepro.2016.01.102

Sururi. (2019). Gagasan Framework Rancangan Kurikulum Vokasi Akuntansi Dengan Inklusi RI 4.0 dan Meme. Politeknik Negeri Sriwijaya. Palembang. 
Tabel 8

Daftar Kantor Jasa Akuntan (KJA) Yang Telah Memperoleh Izin Dari Menteri Keuangan Per 12 September 2018

\begin{tabular}{|c|c|c|c|c|c|c|}
\hline NAMA KJA & NO KMK & $\begin{array}{l}\text { TANGGA } \\
\text { L KMK }\end{array}$ & $\begin{array}{l}\text { PEMIMPIN } \\
\text { KJA }\end{array}$ & ALAMAT & NO TELP & E-MAIL \\
\hline $\begin{array}{l}\text { Fetri, S.E., Ak., } \\
\text { M.M., BKP., } \\
\text { CA }\end{array}$ & $\begin{array}{l}111 / \\
\text { KM.1PPPK/2 } \\
015\end{array}$ & $\begin{array}{l}18 / \\
\text { Desember/2 } \\
015\end{array}$ & Fetri & $\begin{array}{l}\text { Gedung Dana } \\
\text { Graha lt. } 5 \text { No. } 508 \\
\text { RT/RW: 002/005 } \\
\text { Kel: Sei Jodoh Kec: } \\
\text { Batu Ampar Batam } \\
\text { Kepulauan Riau } \\
29432\end{array}$ & 0778-421439 & $\begin{array}{l}\text { fetri.akuntan@gma } \\
\text { il.com }\end{array}$ \\
\hline $\begin{array}{l}\text { Juhli Edi } \\
\text { Simanjuntak }\end{array}$ & $\begin{array}{l}73 / \\
\text { KM.1PPPK/2 } \\
017\end{array}$ & $\begin{array}{l}2 / \\
\text { Agustus/20 } \\
17\end{array}$ & $\begin{array}{l}\text { Juhli Edi } \\
\text { Suranta } \\
\text { Simanjuntak }\end{array}$ & $\begin{array}{l}\text { Jl. Aisyah Sulaiman } \\
\text { KM. } 8 \text { Atas } \\
\text { Komplek Ruko } \\
\text { Blok D No. 17, RT. } \\
\text { 008/004, Kelurahan } \\
\text { Sei Jang, Kec. } \\
\text { Bukit Bestari, Kota } \\
\text { Tanjung Pinang, } \\
\text { Kepri } 29124\end{array}$ & $\begin{array}{l}0771- \\
7335657 \\
0852- \\
63157373\end{array}$ & $\begin{array}{l}\text { juhliedi@yahoo.co } \\
\text { m }\end{array}$ \\
\hline Lilis Susanti & $\begin{array}{l}\text { 29/ } \\
\text { KM.1PPPK/2 } \\
017\end{array}$ & $\begin{array}{l}\text { 17/ } \\
\text { April/2017 }\end{array}$ & Lilis Susanti & $\begin{array}{l}\text { The Central } \\
\text { Business Blok B-1 } \\
\text { No. 18, RT. } \\
003 / 005, \text { Kel. } \\
\text { Sukajadi, Kec. } \\
\text { Batam, Batam } \\
29432\end{array}$ & $\begin{array}{l}0853- \\
75320000\end{array}$ & $\begin{array}{l}\text { lilissusanti18@gm } \\
\text { ail.com }\end{array}$ \\
\hline $\begin{array}{l}\text { PT. Akuntan } \\
\text { Mandiri Sejati }\end{array}$ & $\begin{array}{l}\text { 102/ } \\
\text { KM.1PPPK/2 } \\
015\end{array}$ & $\begin{array}{l}15 / \\
\text { Desember/2 } \\
015\end{array}$ & Erwinta Marius & $\begin{array}{l}\text { Ruko Puri Legenda } \\
\text { Blok C2 No. } 8 \text { RT/ } \\
\text { RW: 004/007 } \\
\text { Kelurahan: Baloi } \\
\text { Permai Kecamatan: } \\
\text { Batam Kota } \\
\text { Batam Kepulauan } \\
\text { Riau 29463 } \\
\text { Komp. Kara }\end{array}$ & $\begin{array}{l}0778- \\
8096193 \\
0778- \\
8096225\end{array}$ & $\begin{array}{l}\text { akuntanmandiriseja } \\
\text { ti@yahoo.com }\end{array}$ \\
\hline $\begin{array}{l}\text { PT. Sembilan } \\
\text { Sembilan } \\
\text { Cahaya }\end{array}$ & $\begin{array}{l}21 / \\
\text { KM.1PPPK/2 } \\
017\end{array}$ & $\begin{array}{l}16 / \\
\text { Maret/2017 }\end{array}$ & $\begin{array}{l}\text { hj. Asmaul } \\
\text { Husna, S.E., } \\
\text { M.M., Ak, CA }\end{array}$ & $\begin{array}{l}\text { Industri Blok A, } \\
\text { No. 10, Batam, } \\
\text { Kepulauan } \\
\text { Riau }\end{array}$ & $0778-324846$ & $\begin{array}{l}\text { asmaulhusna177@ } \\
\text { gmail.com }\end{array}$ \\
\hline Victorius & $\begin{array}{l}91 / \\
\text { KM.1PPPK/2 } \\
016\end{array}$ & $\begin{array}{l}16 / \\
\text { September/ } \\
2016\end{array}$ & $\begin{array}{l}\text { Virgo Lazarus } \\
\text { Pehulisa } \\
\text { Tarigan }\end{array}$ & $\begin{array}{l}\text { Komplek Nusantara } \\
\text { Golden Blok C No. } \\
\text { 3, Jalan Engku } \\
\text { Putri, Batam Center }\end{array}$ & 0778-469129 & $\begin{array}{l}\text { virgopbb@gmail.c } \\
\text { om }\end{array}$ \\
\hline
\end{tabular}

